\title{
Racialization and Aporophobia: Intersecting Discriminations in the Experiences of Non-Western Migrants and Spanish Roma
}

\author{
Zenia Hellgren * (1) and Lorenzo Gabrielli * \\ GRITIM-UPF, Department of Political and Social Sciences, Pompeu Fabra University, 08005 Barcelona, Spain \\ * Correspondence: zenia.hellgren@upf.edu (Z.H.); lorenzo.gabrielli@upf.edu (L.G.)
}

Citation: Hellgren, Zenia, and Lorenzo Gabrielli. 2021. Racialization and Aporophobia: Intersecting Discriminations in the Experiences of Non-Western Migrants and Spanish Roma. Social Sciences 10: 163. https://doi.org/10.3390/socsci 10050163

Academic Editor: Virginie Guiraudon

Received: 8 March 2021

Accepted: 27 April 2021

Published: 6 May 2021

Publisher's Note: MDPI stays neutral with regard to jurisdictional claims in published maps and institutional affiliations.

Copyright: (c) 2021 by the authors. Licensee MDPI, Basel, Switzerland. This article is an open access article distributed under the terms and conditions of the Creative Commons Attribution (CC BY) license (https:/ / creativecommons.org/licenses/by/ $4.0 /)$.

\begin{abstract}
In this article, we address a gap in the scholarship on (super)diversity, discrimination and racism by placing the experiences of non-western migrants and Roma people in the same conceptual framework of stigmatization based on racialization and aporophobia. Including a (formally non-recognized) national minority, the Spanish Roma, in such an analysis implies moving from a framework of superdiversity applied to immigrants to a broader one, which also applies the notion of superdiversity to the racialized citizens of a country, shifting the focus from inner-group features to exogenous othering processes by the mainstream society. We aim to also contribute to the literature on the race-class binary with our empirically grounded analysis of how racialization and aporophobia intersect in the negative stereotyping of people who are cast as outsiders based on both their race/ethnicity and (assumed) socio-economic status. Data from several different research projects on migrant and Roma inclusion/exclusion in Spain were used for the analysis, which focuses on the intersections between race and class in the narratives on exclusion and discrimination by 185 migrant and Roma men and women that were interviewed between 2004 and 2021. The analysis shows that our Roma and migrant respondents perceive forms of discrimination based on racialization and aporophobia that are similar in several ways. In turn, the "double stigmatization" experienced by many of our respondents reinforces their actual precariousness, which may be understood both as a cause and consequence of this stigmatization. We found that these experiences were salient in the narratives of both non-western migrant and Roma respondents who find themselves part of a "racialized underclass" and struggle with finding ways to exit the vicious circle of devalued identities and material deprivation.
\end{abstract}

Keywords: racialization; aporophobia; class; discrimination; immigration; Roma

\section{Introduction}

After having studied different forms of inclusion/exclusion and perceived discrimination among migrants in Catalonia/Spain for nearly two decades, in recent years, we expanded our focus to also include the native Roma population ${ }^{1}$. We found striking similarities between the Roma and the non-western migrant respondents in terms of both experiences of ethno-racially based forms of rejection, and of mistreatment based on being, or being assumed to be, poor. These narratives constitute the empirical basis for the analysis on intersecting discriminations that we will develop in this article, conceptualized as racialization and aporophobia (i.e., rejection of the poor; see Cortina Orts 2017).

The marginalization of the migrant population in a country is often considered, both by scholars and politicians, to be associated with the fact that they are newcomers, because of their role as exploitable workers, or because of cultural differences. From this perspective, immigrant disadvantage is largely expected to diminish over time and across the generations (e.g., Haller et al. 2011; Portes and Zhou 1993; Hadj-Abdou 2019). As Zick et al. (2008) state, discrimination may explain why if this improvement does not take place. However, though it is widely known that the Roma people have suffered marginalization and racism for centuries, and still often are otherized in harmful ways despite 
being native citizens of the countries where they live, in Spain as elsewhere (McGarry 2017; Fejzula 2019; Ringold et al. 2005), research on the Roma has generally been analytically separated from research on migrants.

In this article, we aim to advance the analysis of discrimination and disadvantage in "superdiverse" (Vertovec 2007) societies by placing the Spanish Roma people and non-western migrants in the same conceptual framework of stigmatization based on racialization and aporophobia. While by no means neglecting the specificities of different discriminations related to, for instance, prejudices about a certain ethnic group, culture, religion or origin, for the analytical purposes of this article we will focus on the similarities between experiences of exclusion and rejection that are related to the condition of being (or being assumed to be) poor and racialized. Including Roma people in the analysis implies moving from a framework of superdiversity applied to immigrants (Vertovec 2007) to a broader one, which also applies the notion of superdiversity to the racialized citizens of a country. This will also allow us to switch from a notion of superdiversity that mainly addresses inner-group features-such as nationality and ethno-linguistic characteristics- to a focus on exogenous othering processes resulting in the creation of "diversity".

We argue that in order to conceptualize the exclusion and discrimination that Roma people and non-western migrants are subject to, an intersectional approach taking into account the dimensions of race/ethnicity and class is necessary ${ }^{2}$. We believe that there is a class-related dimension of racialization that cannot be left out of any serious discussion on discrimination (Hellgren 2019). Yet, we also argue that the stigmatization of migrants and Roma people cannot be reduced to mere "aporophobia", as Cortina Orts (2017) claimed in her popular essay on this topic. Several studies highlight the political and economic dynamics of marginalization by the capitalist system. Bhattacharyya (2018, p. 102), for instance, explains that it is possible to analyze racial capitalism by looking at how "economic exploitation and racist othering reinforce and sometimes amplify each other". Waquant (2009), in addition, underlines that an increasing social insecurity is intertwined with the evolution of criminal justice that determines a punishing of the poor; we will incorporate the criminalization of Roma and migrants as a component of the intersection between racialization and aporophobia in our analysis.

Our aim is to provide an empirically grounded contribution to the analytical framework of race and class developed by Balibar and Wallerstein (1991), in light of new conceptual developments in the field of racialization and othering processes, as well as the treatment of the poor in a late capitalist society marked by social inequalities that were seriously aggravated by the Great Recession (Hellgren and Serrano 2019; Marí-Klose and Martínez Pérez 2015; Medina Moral et al. 2010), and currently are further intensified due to the COVID-19 pandemic (FRA 2020a, 2020b; GRITIM-UPF 2020; Fakali 2020). We rely on extensive qualitative data material on the self-perceived discrimination of migrants and Roma people in Spain, collected from several of our research projects ${ }^{3}$. Here, we will use these data in order to examine the race- and class-related dimensions of discrimination, both individually and in intersection. By applying this perspective, our analysis sheds light on the racial dimension of perceived exclusion and discrimination, as well as its intersection with the class stigma.

In the following parts of this article, we will first discuss the historical racialization of Roma people in Spain and how it contributed to create structures of inequality that still continue to define the life conditions of the Roma, before turning our lens to the newer arrivals of racialized people through migration. In this section, we will also situate our work in relation to contemporary research on discrimination against migrants and Roma people. Then, we will provide a theoretically grounded analysis of our key concepts, racialization and aporophobia, and their relevance for a renewed, fundamentally intersectional approach to the debate on race and class. In the empirical section, we will describe our ethnographic data material, and analyze this along the lines of racialization/aporophobia and their intersections. 


\section{Histories of Discrimination: Antigypsyism and Xenophobia in "Superdiverse" Spain}

The Spanish history of racism goes back to the Middle Ages, including the expulsion of Jews and Moors from the country, the colonization of Latin America, the marginalization of the Roma population, and the scientific racism during the 19th and 20th centuries, which under the Franco dictatorship was inspired by contemporary European doctrines on "racial biology" (Van Dijk 2005, p. 70). In contemporary research on othering processes, there is also an increasing focus on borders: the high visibility of irregular crossings at several points of the Spanish borders-Ceuta, Melilla, the Gibraltar straight or more recently the Canary Islands-plays a key role in the demonization of migrants (Gabrielli 2021; Carlotti in this Special Issue). Visual and textual narratives in media and in political discourses tend to overemphasize the weight of the flows of "non-whites", defining them as an "invasion" or an "avalanche", and framing them as a central security threat for the state, the welfare system, or the "national culture", and thereby justifying the "obscene character of exclusion" (De Genova 2013, 2018). In this section, we will provide a contextual background to the exclusion and discrimination of Roma people and more recently arrived, non-western migrants in Spain.

To a great extent, the history of the Roma, or gitanos $^{4}$, in Spain is also a history of persecution and exclusion (Motos Pérez 2009; Martín Sánchez 2018). The construction of Spanish Roma as a group of "others" occurred over time through different political, legal and social mechanisms. Some authors point out the primacy of the legal mechanisms to generate this othering/racialization of the Roma population (Motos Pérez 2009; Vázquez García 2009; Filigrana 2020). Since the late 15th century, Spanish laws specifically targeted the ways of life of the Roma people and the typologies of their economic activities (unpaid work, mainly livestock trade, or work as blacksmiths), and also their place of settlement, the use of their language, their cultural expressions, and their very identification as Roma (e.g., Filigrana 2020; Vázquez García 2009). During these five and a half centuries of legislation, several negative characteristics have been associated with Roma people: vagrants, loafers, cheats, evildoers, crooks, thieves, tricksters, child kidnappers, lazy, idle and criminal people (Motos Pérez 2009; Vázquez García 2009). It is not surprising to see the echoes of this labeling in contemporary stereotypes related to the Roma population in Spain. Moreover, the historical marginalization of the Roma generated economic disadvantage in very concrete terms (exclusion from most economic sectors, stigmatization of "gypsy professions", forced inclusion in low-wage and degrading activities, also through forced labor sanctions), and a mutually reinforcing process in which racialization and class stigma became intimately intertwined. The last racist legislation targeting the Roma population in the country was withdrawn as the democratic constitution of Spain was approved in 1978 (Motos Pérez 2009). Still today, however, despite formally being recognized equal rights to any Spanish citizen, the Roma people suffer from negative prejudices and are overrepresented in situations of poverty and marginalization (Damonti and Arza Porras 2014; Filigrana 2020). Contemporary antigypsyism appears closely linked to aporophobia in social and political narratives (Filigrana 2020; Cortés Gómez and End 2019).

Spain does not recognize ethnic minority statuses, which by several activists has been highlighted as problematic since it results in the lack of data on ethnicity and ethnic discrimination. It is therefore difficult, if not impossible, to give an accurate account of the number of Roma people in the country-currently estimated to be about $2 \%$ of the population (FSG.org 2020) — or the discrimination they face (Agüero Fernández 2020). It is, however, well known that discrimination and social exclusion affect the Roma population severely. Roma children fail in Spanish schools to an alarming extent (Hellgren and Gabrielli 2021; FSG.org 2020) and, as O'Hanlon (2016, p. 7) recently stated: “Roma students aren't in the classrooms, and their history isn't in textbooks: 500 years of Roma contributions to Spain fails to merit a single mention in school history books". Therefore, apparently a vicious circle is continuously reinforced: Roma people are repeatedly mentioned in negative terms, 
as in media articles of "clan fights" and welfare dependence, while non-Roma continue to reject Roma people as classmates, employees, or tenants.

The history of migration to Spain, in turn, is comparably recent in a European perspective. Stimulated by the fast economic growth after the Spanish entry into the European Union in 1986, non-western immigration started to increase in order to cover mainly low-paid, low-qualified positions in sectors such as agriculture, construction or domestic work, rejected by the Spaniards. The proportion of the Spanish population represented by immigrants increased from $0.9 \%$ in 1991 to $11 \%$ in 2020 (representing a small decrease since the peak of $12.20 \%$ in 2010 and $2011^{5}$ ). This migration from northern and sub-Saharan Africa, Latin America, Eastern Europe, and Asia was largely irregular (residence permits were granted subsequently under certain conditions) (Izquierdo 2005; Moreno Fuentes and Callejo 2011; Moreno and Alòs 2015) and, it could be said, led to the gradual formation of a large "migrant precariat" (Standing 2014). Immigration in Spain became closely linked to precariousness (Moreno and Alòs 2015); an immigrant in people's minds would typically be synonymous with a poor, exploitable worker from a non-western country (Hellgren 2019). Just as racialization and aporophobia intersect in the negative prejudices affecting the Roma people, these categories also shape the "immigrant stigma".

The situation of non-western migrants in Spain is similar to that of the Roma people in several regards: immigrants are overrepresented in situations of social exclusion and lacking opportunities (Catalan Government's Integration Report 2016; Marí-Klose and Martínez Pérez 2015; Moreno and Alòs 2015), and immigrant children fail disproportionally in Spanish schools (though numbers are not as bleak as for the Roma) (Bayona and Domingo 2018). Additionally, though there is increasing recognition of ethnic pluralism, at least in Catalonia, in line with the interculturalist policy agenda (Barcelona Interculturality Plan 2010; Catalan Policy Document 2017, 2019), it is unclear to what extent discourses are translated into practice in terms of improved life conditions for migrants. Much of the research on the disadvantage of non-western migrants in Spain focuses on socioeconomic inequality and the links between migration and precarious employment (e.g., ILO 2014; Porthé et al. 2010; Ramos 2020; Moreno and Alòs 2015). However, in recent years, several studies have also emphasized the problem with racism/discrimination, generally by focusing on racialized people's own experiences and perceptions (e.g., CIS 2018; Bobowik et al. 2014; Hellgren 2019; Spanish Government's Report 2020). Simultaneously, discrimination by the police and the criminalization of racialized groups are increasingly highlighted by several Spanish anti-racist actors (SOS Racisme 2020; Rights International Spain 2020). A recent report on stereotypes of Roma people in the Spanish legal system underlines the existence of a large unconscious bias in criminal justice systems that "leads to mistrust of the criminal justice system by Roma people, who define it as both racist and classist, as it discriminates according to race and socio-economic situation" (Rights International Spain 2020, p. 60). Considering the situation in the Barcelona area (where most of the fieldwork upon which this article is based was conducted), a recent report by the Barcelona City Council on discrimination underlines the systematic detention and police stops based on racial profiling, affecting racialized people from the migrant and Roma population (Barcelona City Council 2020, pp. 43-44). Discrimination and racist attitudes are also signaled in access to housing, in the media, and in relation to school segregation (SOS Racisme 2020; Barcelona City Council 2020). Moreover, the Barcelona City Council also stresses the fact that the low number of complaints received by their Office for Non-Discrimination is most likely explained by underreporting, which, in turn, may reflect a widespread lack of trust in the system rather than the absence of actual discrimination, particularly among Roma people (Barcelona City Council 2020). As one of our respondents put it, "if I report when I am discriminated against, it would just be like double discrimination, being humiliated again by the person I report to" (Roma woman, Barcelona, Interview 2020).

At present, the situation has apparently worsened. Both migrants and Roma people were among the groups most severely hit by the financial crisis in 2007-2008 (FSG.org 
2013; ENAR Report 2013-2017; Marí-Klose and Martínez Pérez 2015; Hellgren and Serrano 2019), accentuating the poverty that many of them already lived in. Then, the COVID-19 crisis struck against a country that never fully recovered after the financial collapse post2008. The social and economic consequences are already devastating for people with scarce resources, including a large part of the migrant population (particularly individuals without residence permits) and many Roma people who are highly dependent on incomes from street vending and market sales (GRITIM-UPF 2020; FRA 2020a; Fakali 2020). In addition, there are indications that racism and discrimination are currently growing, a tendency that is intensified by the expansion of the anti-immigrant political party Vox (Spanish Government's Report 2020). As the Fundamental Rights Agency of the EU underlines: "the pandemic is increasingly being used as a pretext to target minorities who already suffer racial discrimination and hate crimes, such as migrants, people of immigrant descent and Roma, particularly on social networks" (FRA 2020a, p. 1). Consistently, several reports by civil society organizations working on rights, discrimination and racism underline an alarming rise of racism and racial discrimination against both migrants and Roma people in Spain during the COVID-19 pandemic (e.g., African Descent/Rights International Spain 2020; Fakali 2020).

\section{Intersecting Discriminations: Racialization and Aporophobia as Mutually Reinforcing Categories}

In contemporary scholarship on racism and discrimination, the intersectional approach requested by Crenshaw (1991) is increasingly common (e.g., Seng 2012; Viruell-Fuentes et al. 2012), though there are different and sometimes contradictory currents in the migration and diversity literature. At present, there is an emerging focus on race and racialization, which has hitherto largely been absent from the European discourses (Small 1994; Dalal 2002; Leach 2002; Grosfoguel 2004; Silverstein 2005; Lentin 2008, 2011, 2015; Vincze 2014; McDowell 2016; Gans 2017; De Genova 2018; Gonzalez-Sobrino and Goss 2019; Johansson 2020). This "racial turn" has recently been fueled by the global Black Lives Matter movement. It links exclusion and disadvantage to the overt or hidden racism that affects many non-white people in European societies, as elsewhere in the world, and reflects the polarization in social research between this perspective on the one hand, and the defenders of the "post-racial society" on the other hand (Leach 2002; Waquant 2009; Viruell-Fuentes et al. 2012; Bhattacharyya 2018; Bhattacharyya et al. 2019; Warmington 2020). At least for some, indeed, to recognize the existence of racial hierarchies in European societies collides with the highly held ideal, or illusion, that there is equality of opportunities (e.g., Leach 2002; Silverstein 2005; Lentin 2008; Vincze 2014; Hellgren 2019). Moreover, in the broader context of research on racism and discrimination, antigypsyism is often approached by focusing on the specificity of the kinds of racism and exclusion that the Roma are exposed to (e.g., Cortés Gómez and End 2019; O’Hanlon 2016). Without questioning the purposiveness of such an approach, both at the analytical and claims-making levels, in this article we do instead intentionally focus on the similarities between the stigmatization of Roma people and of migrants. Research on poverty and social class, in turn, is a classical field in the social sciences. It seems to have experienced a kind of renaissance in recent years, not the least in the wake of the enormous attention to Standing's work on the "new underclass", the precariat (Standing 2014), and the impoverishment of large segments of people across the western world since the Great Recession (Marí-Klose and Martínez Pérez 2015; Hellgren and Serrano 2019). By this article, we wish to contribute to a more explicit focus on the specific situation that the racialized members of this precariat face.

We situate our work in the intersection between the fields of race and class, bringing together two frameworks that have not only been analytically separated, but often placed in direct opposition to each other (Bhattacharyya et al. 2019; Sayyid 2017; Hollinger 2011). Marxist scholars have, for instance, accused defenders of Critical Race Theory and other scholars focusing on race/racialization for downplaying the recognition of class inequalities (Warmington 2020). In this theoretical section, we will further define how we use the concepts of racialization and aporophobia, and discuss the relationship between 
them. Indeed, the debate on the intersections between race and class is not a new one (see, for instance, the seminal work by Balibar and Wallerstein 1991). However, in using the concepts racialization and aporophobia (meaning, as we apply it: rejection or stigmatization of the poor) rather than possible alternatives such as simply talking of "race/ethnicity", "poverty", or "social class", we intend to place emphasis on how people are categorized and assigned socially constructed categories (being racialized, or labeled as "undeserving poor") rather than what they objectively "are", which is a precondition for discrimination to occur and not only disadvantage. Thus, the labeling itself and its consequences are what primarily interest us.

First, we understand racialization as the differentiation between people based on "racial" characteristics, most typically skin color, but also, for instance, appearance, clothes or other items that contribute to a person being identified as a member of a certain ethnic, cultural or religious minority that is framed as "different" (often with negative connotations) in relation to the (white, western) majority society (Gans 2017; Burgett and Hendler 2014; Dalal 2002). Omi and Winant ([1986] 2015, p. 111) in turn define racialization as "the extension of racial meaning to a previously racially unclassified relationship, social practice, or group". Racialization then becomes a way to understand racial meanings both at the micro and macro level. Following Small (1994, p. 30), "race relations are linked with economic, employment, politics and demography issues, as well as nationality, language and religion". This author points out two main axes of a racialization theory, involving power and social stratification. Firstly, he highlights the differential power relations among those defining race and those who are defined. Secondly, he stresses the need to look at the intersection of racialized relations at the economic, political and social levels (Small 1994).

How such differentiations are made has tangible consequences for the treatment and opportunities of the affected individuals. There are numerous studies confirming the discrimination that immigrants and racialized minorities suffer in European societies, and the severe consequences it has for them in terms of damaged material and psychological wellbeing (e.g., Zick et al. 2008; Crul and Schneider 2009; Safi 2010; Bobowik et al. 2014; ENAR Report 2013-2017). Moreover, though there are several reports on the serious increase in racist hate crimes, hate speech and other overtly aggressive manifestations of xenophobia across Europe (Cortés Gómez and End 2019; 2020a; FRA 2019a, 2019b), racialization and the discrimination it results in are most often manifested as subtle forms of rejection that can hardly be proved. Not seldom, even the person affected by it cannot be fully certain that he or she has actually not been selected for a job position or a rental contract because of his or her ethno-racial features. However, when individual incidents of rejection are repeated, across the life course and among large numbers of people with similar characteristics, at some point these incidents turn into patterns of exclusion. In Lamont and Molnár's (2002, p. 138) words, they become social boundaries; “objectified forms of social differences manifested in unequal access to and unequal distribution of resources (material and nonmaterial) and social opportunities". Precisely the relationship between racialization and such unequal access to and distribution of resources is fundamental for our argumentation, in which we focus on racial categories and poverty as mutually reinforcing elements rather than debating "which one trumps the other" (Balibar and Wallerstein 1991; Cortina Orts 2017; Warmington 2020).

Second, the concept of aporophobia, conceived by the Spanish philosopher Adela Cortina Orts (2017) by merging the two ancient Greek words áporos (indigent, poor) and fobia, has not yet become "mainstreamed" or accepted at a general level in academia, though there has been at least one early, tentative attempt to start constructing a full theory of aporophobia (see Comim et al. 2020). Thus, this is still work in progress, to which we aim to contribute. We find that the term aporophobia is particularly useful, and significantly different from concepts such as "social class" or "poverty" in that it specifically addresses stigmatization/discrimination of the poor, not the poverty itself or the social exclusion it generates, as is the case for much of the literature on class (Warmington 2020). In addition, we understand the relationship between actual poverty and aporophobia 
as complementary and mutually reinforcing: the first refers to actual deprivation, the other to the contempt that this (real or assumed) socio-economic vulnerability causes. As Comim et al. (2020) accurately point out, aporophobia is a concept that focuses on what others - that is, the established, non-poor classes ${ }^{6}$ - think of poor people. It may thereby serve to problematize the stereotyping, and blaming, of the poor rather than focusing on the poor themselves as "the problem". This represents a relational and potentially more controversial, conflict-focused approach to social exclusion, which we find particularly useful for our focus on discrimination.

Third, we shift focus from each of these concepts defined separately to the intersection between them. Starting by again turning to Cortina, at the core of her defense for the concept of aporophobia lies the belief that the rejection of poor people overshadows other forms of stigmatization, such as racism/xenophobia, and that racialized others therefore are only stigmatized in case they are also poor (Cortina Orts 2017). Similar to this line of argumentation, Balibar and Wallerstein (1991) argue that class is more relevant for who is labeled as an "immigrant" than race or ethnicity. Indeed, we recognize the importance of the wealth/poverty binary and the stigmatization of all poor people, racialized or not. However, where Balibar and Wallerstein, just as Cortina, make the case that a wealthy individual, though visibly different in racial terms, will be fully accepted because of his or her class or wealth, we shall instead argue, based on our empirical studies, that racialization as a mechanism of exclusion operates alone as well as in intersection with aporophobia. To use a concrete example, a black business man or football star may also be, and too often is, subject to racist insults, to institutional discrimination or other forms of mistreatment based on racialization. In practice, moreover, the boundaries between the concepts are often blurred and mutually reinforcing. Gans (2017), as well as a declaration of the UN's International Organization for Migration (IOM Website 2020), provide useful examples of how discrimination based on racialization accentuates and perpetuates poverty, since racialized individuals are often denied access to the means that could improve their situation, such as quality employment. In such cases, to put it simply: it is rather a matter of people staying poor because they are racialized, than of being racialized because they are poor others.

We argue that racialization and aporophobia are two central categories of disadvantage and discrimination by themselves, and are also intimately intertwined in the specific forms of discrimination that affect non-white migrants and Roma people. Additionally, which is important, both racialization and aporophobia are concepts that focus on what the (white, non-poor) majority thinks of others and how they are constructed as fundamentally different, with stigmatizing consequences.

\section{The Ethnographic Data Material}

This article is based on extensive qualitative fieldwork about racialized people's perceptions on discrimination and belonging, conducted within the frameworks of several research projects in Spain, mostly in the autonomous region of Catalonia with emphasis on the city of Barcelona, between 2004 and 2021 (see footnotes 1 and 3). The literal transcripts from altogether 185 interviews with migrants (both with regular and irregular legal status) from North and sub-Saharan Africa, Latin America, Asia, the Middle East, and Eastern Europe, Spanish-born descendants of immigrants, and Roma men and women were used. These different research projects all had their own principal foci, including the life conditions of undocumented migrants, migrant claims-making, precarious work, self-perceptions on integration, school inclusion, and discrimination. However, there were also important similarities between them, justifying their inclusion in the present analysis. In all the projects, an inductive approach was applied. Semi-structured or unstructured interviews were conducted, in which the respondents were encouraged to talk openly about their experiences of racism, discrimination, exclusion, and disadvantage. For all of the respondents that are included in this article, such experiences had a significant 
influence on their sense of belonging and identification with society as a whole, as well as their wellbeing in general.

The transcripts had already been analyzed and coded with the data analysis software Dedoose (Los Angeles, CA, USA: SocioCultural Research Consultants) in relation to the research projects that they correspond to, and were now recoded for the purpose of this article. Specifically, we traced the experiences of being exposed to racism/ethnic discrimination and to stigmatization based on being, or being assumed to be, poor, applying the two main codes of "racialization" and "aporophobia". For the racialization code, we found that experiences of othering and discrimination based on being labeled as "nonwhite" appeared as a determinant for the respondents' life quality and sense of belonging throughout the interviews, despite their differences in terms of origin, migrant trajectories, socio-economic situations, different contexts, and at different times. For the aporophobia code, we found that there was a central difference between those respondents who lived in actual situations of poverty and precariousness, and those who were rather subject to classist prejudice and derogatory treatment for being assumed to be poor, marginalized, "problematic", or even criminal, based on factors such physical appearance, neighborhood of residence, or race/ethnicity, thus revealing how intimately intertwined the concepts of racialization and aporophobia are in the experiences of these persons.

\section{Migrant and Roma Experiences of Exclusion and Disadvantage}

In this section, we will describe the results of the empirical analysis. We have already discussed how the class dimension often intersects with ethno-racial differentiation, and it may indeed be hard, if even possible, to distinguish between these grounds for discriminatory treatment, exclusion or disadvantage (Hellgren 2019). For the analytical purposes of this section, to the extent we considered this reasonable, we aimed to apply the conceptual distinction used during the coding between experiences of racialization, on the one hand, and of aporophobia, or class-related stigmatization, on the other, while also illustrating how numerous lived experiences of discrimination precisely reflect their intersection.

\subsection{Self-Perceived Racialization among Roma People and Migrants}

As stated above, it may be difficult for somebody belonging to several categories of discrimination ${ }^{7}$, for instance, a female migrant domestic worker from the Dominican Republic, to determine whether she is being discriminated against for being poor, for being a woman, or for being racialized, which is why an intersectional perspective is fundamental in discrimination research overall (e.g., Seng 2012; Viruell-Fuentes et al. 2012; Young 2009). In this article, we apply an intersectional approach by also analytically separating these concepts, in order to shed light on "what is what" and better understand their feedback.

Indeed, discrimination is often expressed as subtle forms of rejection, which sometimes makes it difficult even for the person affected by it to feel sure of what actually happened. Not being chosen for a job or a rental contract, or yet more subtle, constantly perceiving that public servants, hospital staff or the teacher at the children's school act annoyed, disliking or derogatively, are common experiences among the racialized people we interviewed, but can hardly ever be contested due precisely to their subtleness.

In this section, we focus on the many subtle and overt experiences of racism and discrimination that are perceived as solely or primarily based on ethno-racial differentiation, regardless of the person's socio-economic level. Most typically, this kind of discrimination is related to skin color, which is reflected through many of the interviews and is particularly tangible in the black respondents' narratives.

"I have a high level of Spanish and Catalan [level C diplomas], and native English and French, and I took a course to become a flight attendant. At the end there was a test, those who approved were sent to an interview at a large airline. I was the only black person there but I didn't think it mattered. But then ... none of the others spoke foreign languages and I scored third on the test, but out of 13 people, 12 were hired, everyone except me. They told me outright that 'at this airline we 
are not used to working with colored people, you should move to London, or France, they are more used to immigration there'. I told him how unfair it was, I scored higher than most and speak more languages, and I'm the one who should have to move abroad to find work?" Male migrant from Cameroon, 2015.

Additionally, among people who are not black, but considered "darker than average" (or non-white), skin and hair color, or characteristic features recognized as indicators of a certain ethnic origin, are mentioned as common grounds for being treated as less, among, for instance, North African and Latin American migrants, and Roma people.

"Being as dark as I am, they either discriminate me for being gypsy or because they think I am a 'Moor' [moro], it doesn't really make a difference". Roma man, 2017.

"My daughter is born here, but they will always look at her and say, 'that's the Moor's daughter'. Because I know children of Moroccans, born here, speaking perfect Catalan, but they are always called the 'Moors'. And look at France, Holland, Germany ... they have 4 generations of immigrants but it's still the same. Nothing changes, we will always be immigrants for them, always". Female migrant from Morocco, 2015.

However, just as Silverstein (2005), we understand racialization as broader than limited to the most typical, visual markers of "race". Being racialized and discriminated against based on a visible difference that is valued negatively by the native majority society is also a common experience among migrants and Roma who could pass for white (Piper 1996). Such markers of difference may be, for instance, religious clothing and attributes, Roma women's way of dressing, which often attracts attention in Spain, or ways of speaking and acting that are otherized.

"I started wearing the hijab during my second year at the university, I was a more religious person then. I studied a lot about Islam and decided to use the headscarf. And at first I felt very happy, but then I started feeling bad about how people stared at me in the streets, and always having to explain to everyone why I wore the hijab, that I decided myself and was not oppressed ... after a year, I decided to take it off. It's only when I wear the hijab that people notice that I'm not from here". Spanish woman of Moroccan origin, 2014.

For many of the respondents, there is a clear link between being racialized and not having the same opportunities as other, whiter migrants or ethnic majority citizens. Some express a critical consciousness of such injustice, which they attribute to discrimination, though most of them rather take this situation for granted and doubt that it will change for the better.

"Very few Latin Americans or people from Black Africa, or Asia, have become included in politics, or in the security forces ... it is very difficult to find black or Latin politicians in the governments or city councils. This is a covered-up disintegration, we can say that ok, there are migrants here, they integrate, but as third-degree citizens. In other parts of Europe you can see black police officers or members of parliament, that is very rare here". Male migrant from Peru, 2015.

"One of my daughters is blond, blue-eyed, she looks German. If she doesn't dress up like a gypsy you know, with all the jewelry and stuff, nobody thinks that she is one. But my other daughter is so dark, she looks Pakistani ... it will be much more difficult for her, for sure". Roma woman, 2018.

Moreover, there is further one category of racialization that proved relevant for our findings, and that serves to illustrate how the boundaries between racialization and "aporophobia" become blurred. People who are not visibly different from the native majority or from other "high-status groups" (such as Eastern European migrants resembling western expats in Spain) still had several experiences of racialization that were closely related to 
prejudices about their (poor) countries of origin, and other people's ideas of themselves as being needy, desperate and in a socio-economically subordinate position, sometimes bringing about contempt. In these cases, it was the origin rather than general class-related markers that created rejection-just saying where one comes from would often be enough to receive a negative reaction.

\subsection{Self-Perceptions on Aporophobia}

In this section, we will illustrate some of the experiences of our respondents that are related to their perceptions on being subject to classist stigmatization, that is, aporophobia. In many cases, these experiences do not have to be different from those of poor or "underclass" white people from the ethnic majority population; it is when they intersect with the experiences of racialization as described above that disadvantage is further accentuated. It is important to note that though many people of migrant or Roma origin in Spain indeed live in situations of economic scarcity, or even, and in the wake of the COVID-19 crisis increasingly, acute precariousness, the "aporophobic stigmatization" that people in these categories are often subject to is not necessarily grounded in actual poverty. To this categorization, we therefore add the stigmatization of people perceived as "underclass"; for instance, people who dress and act according to suburban ghettoish aesthetics, which, in combination with being "dark", non-white, easily generates a specific form of "lowlife" label. The "ghetto underclass" label—in itself encompassing both racialization and aporophobia-is, in turn, closely related to the Roma and migrant respondents' frequent experiences of criminalization, such as being stopped and questioned by the police or security staff on a regular basis, based on how they look and where they live and/or move:

"When I travel by car, if we are 3 or 4 gypsies in the car, the police always stop us, always. They ask "where are you going, what are you doing?" And if I ask why they only stop us and let all the other cars just pass by, they say "man, 4 gypsies in a car, where are you going, how could we not stop you?" Roma man, 2021.

"The police always stopped me when I was younger, I mean, being Moroccan, and living in a shanty neighborhood ... that made me want to prove them wrong, I wanted to become a police officer myself". Spanish man of Moroccan origin, 2020.

"The security guard always walks up close behind me when I enter a supermarket, it is so humiliating and awkward. The other day one guard asked me to open my jacket, just like that, saying "I'm sure you're robbing, all you gypsy women come here to steal". Roma woman, 2020.

The relationship between the concepts becomes yet more tangible when we compare the experiences of African-origin respondents with different socio-economic statuses. The first respondent quoted below is a black female migrant working as a waitress in Barcelona, while the second one is a young black woman of African descent who grew up in a comparably wealthy, Barcelona-based family, went to an international school and is fluent in several languages. She has largely perceived that her Africanity is treated as something exotic, sometimes stereotypical, but she has, in her own words, not felt very discriminated against in negative ways, and attributes this to her high social status. The quotes serve to illustrate how racialization strikes differently depending on whether it is combined with aporophobia or not:

"It's like you have to apologize for existing all the time. Everybody thinks that we are poor and will rob them. People here take a deep bow when they meet someone rich, they feel so small, but rich people are very scared. And at the same time they don't even think we have the right to look them in the eyes". Female migrant from Cameroon, 2015.

"People always liked to touch my hair and so [ ... ] But this [discrimination] is simply an economic question. If I were in a position in which I was forced to 
become a prostitute and walk Las Ramblas at night, people would surely treat me differently". Spanish woman of Congolese origin, 2015.

The intersections between racialization and aporophobia (and, indeed, gender) are perhaps most explicitly expressed in the situations of many female migrant domestic workers in Spain, who represent a significant share of our sample ${ }^{8}$. In a context of financial crisis and tough competition also over the most precarious jobs, ethno-racial hierarchies are accentuated. Several of the migrant domestic worker respondents with the most explicit experiences of racialization and racism, many of whom are Latin American women from countries such as Bolivia, Honduras and Ecuador, with an appearance that is perceived as "indigenous", explain that they are constantly rejected or treated without respect based on the perception of them as poor, uncultured, "savage" and incompatible with "European manners". Again, racialization and aporophobia intersect in the negative stereotyping of certain nationalities and countries of origin.

"The lady I used to work for told me all kinds of things, that I didn't know how things should be done, that I couldn't speak properly, things about my country ... I wanted to say look, we have television there too, we live in houses, not small apartments like here, you are the ones who are poor". Female Bolivian migrant/domestic worker, 2014.

"To be honest it is very difficult for me to find a job. The families look at you, and according to their prototypes and preferences, they don't like someone like me. They tell me "cut your hair like this, style yourself like that". There is much everyday racism, and prejudice against my country, I have not felt very valued in Spain I must say". Female Bolivian migrant/domestic worker, 2013.

The interviews with workers in the domestic sector reflect that native workers are preferred over migrants if available, and that ethnic hierarchies operate by also stratifying among migrants, favoring those perceived as whiter and "more western" over the more racialized workers (Hellgren and Serrano 2019). However, as the next quote shows, the exploitation that affects workers who are completely dependent on their wages and whose bargaining power is extremely low may be "colourblind" and strike migrants and natives equally:

"I was working in a textile factory in Gavà [outside of Barcelona], the owners were Spanish but they refused to fix the papers for us. They locked us up inside the factories like the Chinese do, we could not exit between 8 in the morning and $7 \mathrm{pm}$, we only had a 15 minutes break during all that time. Lots of people worked there, Spaniards too at first, but they couldn't stand it. We were treated like garbage". Female Romanian migrant, 2014.

Nevertheless, in these cases, the origin usually places the migrant worker in a more vulnerable position with fewer exit options compared to poor natives.

The different narratives on discrimination and disadvantage that we shared in this section reflect different dimensions of how racialization and aporophobia, alone or in intersection, operate to otherize people, denying them the right to form part of the "mainstream citizenry", the collective "us". A common consequence of repeatedly being treated in ways as those described above is what several of the respondents define in terms of a normalization or interiorization of discrimination, so that those affected by it take for granted that they will continue to suffer from it, an experience that may even be passed on from one generation to the next:

"We know since we're children that as Roma we are always discriminated against. There has always been persecution. This is something that we transmit from parents to children. If I go somewhere to look for a job and I'm discriminated for being a gypsy ... oh. That is just what I expected, because it happened to my father, to my grandfather and to my great grandfather. We are used to it". Roma man, 2020. 
Perhaps the narratives of those who constantly avoid places and situations where they, based on previous experiences, consider it likely to suffer discrimination are the ones that most explicitly make clear how stigmatization based on racialization and aporophobia harms social mobility and contributes to perpetuate exclusion and disadvantage through the reproduction of a differentiated citizenship.

\section{Concluding Discussion}

This article has intended to fill a gap in the literature on (super)diversity, discrimination and racism by including migrants and racialized citizens (the Roma) in the same conceptual framework, and adding the concept of aporophobia to the analysis of the stigmatization of racialized others. We have applied an intersectional approach in order to provide an empirically grounded contribution to develop the underexplored relations between racialization and aporophobia, complementary to the vast scholarship on race and class. This intersectional analysis shows that there is a class-related dimension of racialization that cannot be neglected in discrimination debates, and also that the stigmatization of migrants and racialized national minority groups, such as the Spanish Roma, cannot be reduced to mere "aporophobia". Our ethnographic data lend support to our initial assumption that non-western migrants' and Roma people's experiences of racism, discrimination, exclusion, and disadvantage based on racialization and aporophobia are similar in several ways. We found that these experiences were salient in the narratives of both non-western migrant and Roma respondents who form part of a "racialized underclass", which is reinforced by factors such as living in a marginalized housing area with a "ghetto label" (as has earlier been underlined for the Roma in the Italian case by Claps and Vitale 2011; and in the French case by Vacca et al. 2021), and reversely, alleviated when there is the absence of poverty and "underclass markers". Analyzing the narratives of middle class non-white respondents, however, also lent further support to our assumption that racialization also generates discrimination when it does not intersect with aporophobia. This is indeed hardly remarkable; it basically just suggests that "racism exists" as a category in itself (Warmington 2020). In turn, the "double stigmatization" that many of our respondents were subject to brings about a double disadvantage that is mutually reinforcing: real precariousness and prejudices related both to (assumed) ethno-racial identities and (assumed) poverty. In practical situations, this stigmatization often translates into derogative treatment related to both racialization (racist insults, rejection based on physical appearance and/or assumptions about cultural or religious traits, etc.) and aporophobia (insults related to assumed welfare dependence, assumed unwillingness to work, labels such as "low-level/problematic/ghetto people", etc.).

Before concluding this discussion, we wish to say a few words about the relevance of applying a framework of superdiversity to our work. In his seminal theorization around the concept of superdiversity, Vertovec underlines that this new demographic reality is the result of a complex interplay of factors related to newcomers, including country of origin, ethnicity, languages, religious traditions, migration channels, legal status (the access to rights), migrants' human capital, access to employment, locality, transnationalism, and responses by local authorities, service providers and local residents (Vertovec 2007, p. 1049). Including both Roma people and non-western migrants in our analysis implies moving from a framework of superdiversity that mainly focuses on migrants to a broader one, including the racialized citizens of a country. This allows us to displace the focus of superdiversity from inner-group features to the exogenous othering processes. We consider our analysis as complementary to Vertovec's understanding of superdiversity, in showing that racialization and othering processes may affect both newcomers and racialized national minority groups, following very similar dynamics and producing similar outcomes. Moreover, our analysis underlines that when these racialization processes pair up with aporophobia, reflecting either severe poverty and real marginalization or "just" the prejudice that racialized people are also poor, disadvantage is accentuated. In this sense, racialized citizens such as the Roma people indeed have more in common with non-western migrants than 
with non-racialized members of the mainstream society-though it is important to bear in mind that class draws sharp lines that also significantly determine the life conditions and opportunities among white natives.

Author Contributions: Conceptualization, Z.H. and L.G.; methodology, Z.H.; software, Z.H. and L.G.; validation, Z.H. and L.G.; formal analysis, Z.H. and L.G.; investigation, Z.H. and L.G.; resources, Z.H. and L.G.; data curation, Z.H.; writing-original draft preparation, Z.H. and L.G.; writing-review and editing, Z.H. and L.G.; visualization, Z.H. and L.G.; supervision, Z.H.; project administration, Z.H. and L.G.; funding acquisition, Z.H. All authors have read and agreed to the published version of the manuscript.

Funding: This research was funded by the Rights, Equality and Citizenship (REC) Programme of the European Union under Grant Agreement number 881875, within the framework of the researchaction project AGREP (Action program for effective reporting of anti-gypsyism and discrimination), with Zenia Hellgren as Principal Investigator (PI). The content of this publication represents the views of the authors only and is their sole respon-sibility. The European Commission does not accept any responsibility for use that may be made of the information it contains.

Institutional Review Board Statement: The study was conducted according to the guidelines of the Data Protection Officer of the Universitat Pompeu Fabra, which has reviewed the material submitted to the Institutional Committee for Ethical Review of Projects (CIREP-UPF) by Zenia Hellgren, Principal Investigator of the project Action program for effective reporting of antigypsyism and discrimination-AGREP-Application Nr. 0188 and 0144.

Informed Consent Statement: Informed consent was obtained from all subjects involved in the study.

Data Availability Statement: Not applicable.

Conflicts of Interest: The authors declare no conflict of interest.

\section{Notes}

1 We have directed two recent research-action projects on Roma inclusion and struggles against anti-gypsyism: AGREP (Action program for effective reporting of anti-gypsyism and discrimination), co-funded by the Rights, Equality and Citizenship (REC) Programme of the European Union under Grant Agreement number 881875; and VAKERIPEN (Roma inclusion in education: fostering constructive attitudes and good practices in the Barcelona area), co-funded by the Rights, Equality and Citizenship (REC) Programme of the European Union under Grant Agreement JUST/2015/RDIS/AG/DISC/9372. This article is partly based on data from both these projects. It should be noted that though more than half of the respondents are women, the gender dimension is not included in the analysis for the reason that it was not as salient as a category of self-perceived discrimination and exclusion in the interviews (which focused on the relationship between the (racialized) respondents and the ethnic majority society) as race and class.

2 It should be noted that though more than half of the respondents are women, the gender dimension is not included in the analysis for the reason that it was not as salient as a category of self-perceived discrimination and exclusion in the interviews (which focused on the relationship between the (racialized) respondents and the ethnic majority society) as race and class.

3 Including, besides the two projects already mentioned in footnote 1, the following research projects involving one or both of the authors: REPCAT (The Role of the Ethnic Majority in Integration Processes: Attitudes and Practices towards Immigrants in Catalan Institutions). Funded by a Marie Skłodowska-Curie Individual Fellowship under Grant Agreement: 747075-REPCAT-H2020-MSCA-IF-2016/H2020-MSCA-IF-2016. 2018-2020. PI: Zenia Hellgren; DIASPORA LINK: Transnational Diaspora Entrepreneurship as a Development Link between Home and Residence Countries. Funded by the European Commission, H2020 Marie Curie Actions RISE; IMMIGRANTS' PERCEPTIONS ON INTEGRATION IN TWO INSTITUTIONAL FRAMEWORKS, SWEDEN AND SPAIN. Funded by a postdoctoral grant from the research foundation ahlstromska.se/Stockholm University. PI: Zenia Hellgren; FAMILIES AND SOCIETIES. Funded by the European Union's Seventh Framework Programme). WP9.8: Migration and Care (on the labor conditions and life situations of migrant domestic workers) in Madrid, Barcelona and Stockholm.

4 The Spanish or Catalan word for "gypsy" is widely used and accepted by Spanish Roma people and is also the term generally applied in, for instance, policy programs and other official documents about the Roma population 
(e.g., Pla Integral del Poble Gitano 2017-2020); however, depending on how it is used, it can also have derogative connotations.

5 Own elaboration based on data of INE (Instituto Nacional de Estadistica), Main series of population data, Continuous register (Padron Municipal) and Observatorio Permanente de la Inmigración (OPI), Main series.

6 Indeed, the dichotomy of "majority vs. minority" that is often used in diversity studies can also be applied to studies on the relations between poor and "non-poor".

7 For instance, the European Union's anti-discrimination directives apply an extensive list of such categories in declaring that discrimination on the grounds of "sex, race, colour, ethnic or social origin, genetic features, language, religion or belief, political or any other opinion, membership of a national minority, property, birth, disability, age or sexual orientation shall be prohibited" (European Commission Key Note Speech 2020).

8 The transcripts from 60 interviews with migrant domestic workers in Madrid and Barcelona, from the EU funded project Families and Societies (see footnote 3), were used for this article.

\section{References}

African Descent/Rights International Spain. 2020. Crisis Sanitaria COVID-19. Racismo y Xenofobia Durante el Estado de Alarma en España. Available online: http://www.nadiesinfuturo.org/IMG/pdf/INF_Racismo_y_Xenofobia_Est_de_Alarma.pdf (accessed on 16 April 2021).

Agüero Fernández, Silvia. 2020. Informe Sobre la Situación del Pueblo Gitano en España. Pretendemos Gitanizar el Mundo/Plataforma Ciudadana Rosa Cortés por la Memoria Gitana/Camelamos. Available online: https://arainfo.org/wordpress/wp-content/ uploads/2020/04/Informe-situaci\%C3\%B3n-Pueblo-Gitano.Final_.pdf (accessed on 18 April 2021).

Balibar, Etienne, and Immanuel Wallerstein, eds. 1991. Race, Nation, Class. Ambiguous Identities. London: Verso.

Barcelona City Council. 2020. Report: Informe de l'Observatori de les Discriminacions a Barcelona 2019. Available online: https://ajuntament.barcelona.cat/premsa/wp-content/uploads/2020/05/INFORME_DISCRIMINACIO_2019_A4_CA-1.pdf (accessed on 18 April 2021).

Barcelona Interculturality Plan. 2010. Barcelona City Council. Available online: https:/ / ajuntament.barcelona.cat/bcnacciointercultural/ sites/default/files/documentos/web_bcn_angles.pdf (accessed on 16 April 2021).

Bayona, Jordi, and Andreu Domingo. 2018. El fracaso escolar de los descendientes de la inmigración en Cataluña: Más que una asignatura pendiente. Working paper, Centre d'Estudis Demogràfics, UAB, Barcelona. Available online: https://ced.uab.cat/PD/ PerspectivesDemografiques_011_ESP.pdf (accessed on 3 March 2021).

Bhattacharyya, Gargi. 2018. Rethinking Racial Capitalism. London: Rowmam \& Littlefield.

Bhattacharyya, Gargi, Satnam Virdee, and Aaron Winter. 2019. Revisiting histories of anti-racist thought and activism. Identities 27: 1-19. [CrossRef]

Bobowik, Magdalena, Nekane Basabe, and Darío Páez. 2014. Heroes of Adjustment: Immigrants' Stigma and Identity Management. International Journal of Intercultural Relations 41: 112-24. [CrossRef]

Burgett, Bruce, and Glenn Hendler. 2014. Keywords for American Cultural Studies. New York: New York University Press.

Catalan Government's Integration Report. 2016. Available online: https://treballiaferssocials.gencat.cat/web/.content/03ambits_ tematics /05immigracio_refugi/dades_immigracio/informe_integracio/2015/EN_Informe-integracio-immigracio-2015.pdf (accessed on 25 November 2020).

Catalan Policy Document. 2017. Citizenship and Migration Plan 2017-2020. Available online: http://treballiaferssocials.gencat.cat/ web/.content/01departament/08publicacions/ambits_tematics/immigracio/Plans_i_programes/06plainmigracio_cat_2017 _2020/Pla_inmigracioue_CAT_OK.pdf (accessed on 12 March 2021).

Catalan Policy Document. 2019. The Catalan Government's Diversity Management Guide “Fer nova Ciutadania des del Món Local Propostes per a la Inclusió, la Interacció i la Diversitat". Available online: https://treballiaferssocials.gencat.cat/ca/el_ departament/publicacions/immigracio/publicacions_fora_de_col_leccio/Fer-nova-ciutadania/ (accessed on 12 March 2021).

CIS (Spanish Center for Sociological Research). 2018. Report: Evolución de la Discriminación en España. Madrid: CIS.

Claps, Enrico, and Tommaso Vitale. 2011. Not Always the Same Old Story: Spatial Segregation and Feelings of Dislike against Roma and Sinti in Large Cities and Medium-Size Towns in Italy. In Multi-Disciplinary Approaches to Romany Studies. Budapest: Central European University Press, pp. 228-53.

Comim, Flavio, Mihály Tamás Borsi, and Octasiano Valerio Mendoza. 2020. The Multi-dimensions of Aporophobia. MPRA Paper n. 103124. Available online: https:/ / mpra.ub.uni-muenchen.de/103124/1/MPRA_paper_103124.pdf (accessed on 13 April 2021).

Cortés Gómez, Ismael, and Markus End, eds. 2019. Dimensions of Antigypsyism in Europe. Brussels: ENAR.

Cortina Orts, Adela. 2017. Aporofobia, el Rechazo al Pobre. Un Desafío para la Sociedad Democrática. Barcelona: Paidos.

Crenshaw, Kimberle. 1991. Mapping the Margins: Intersectionality, Identity Politics, and Violence against Women of Color. Stanford Law Review 43: 1241-99. [CrossRef]

Crul, Maurice, and Jens Schneider. 2009. The Second Generation in Europe: Education and the Transition to the Labour Market. Amsterdam: TIES. Available online: http:/ / hdl.handle.net/11245/1.307408 (accessed on 1 December 2020).

Dalal, Farhad. 2002. Race, Colour and the Processes of Racialization. Sussex: Brunner-Routledge. 
Damonti, Paola, and Javier Arza Porras. 2014. Exclusión en la Comunidad Gitana. Una Brecha Social que Persiste y se Agrava. Fundación Foessa, Documento de Trabajo 3.5. Available online: http:/ /www.foessa2014.es/informe/uploaded/documentos_ trabajo/15102014151523_8331.pdf (accessed on 8 February 2021).

De Genova, Nicholas. 2013. Spectacles of migrant 'illegality': The scene of exclusion, the obscene of inclusion. Ethnic and Racial Studies 36: 1180-98. [CrossRef]

De Genova, Nicholas. 2018. The "migrant crisis" as racial crisis: Do Black Lives Matter in Europe? Ethnic and Racial Studies 41: 1765-82. [CrossRef]

ENAR (European Network against Racism) Shadow Report. 2013-2017. Racism and Discrimination in Employment in Europe. Available online: https:/ / www.enar-eu.org/IMG/pdf/shadowreport_2016x2017_long_final_lowres.pdf (accessed on 5 March 2021).

European Commission Key Note Speech. 2020. Available online: https://ec.europa.eu/commission/commissioners/2019-202 4/johansson/announcements/black-lives-matter-europes-anti-racism-moment-european-policy-centre-keynote-address-16 -july-2020_en (accessed on 18 April 2021).

Fakali (Federación de Associaciones de Mujeres Gitanas). 2020. Fakali, antigitanismo y Covid-19. Informe del Impacto del Antigitanismo en la Sociedad del Coronavirus. Available online: https://fakali.org/wp-content/uploads/2020/12/Informe-FAKALIAntigitanismo-y-Covid-19.pdf (accessed on 27 April 2021).

Fejzula, Sebijan. 2019. The Anti-Roma Europe: Modern ways of disciplining the Roma body in urban spaces. Revista Direito e Práxis 10: 2097-16. [CrossRef]

Filigrana, Pastora. 2020. El pueblo Gitano Contra el Sistema-Mundo. Reflexiones desde una Militancia Feminista y Anticapitalista. Madrid: Akal.

FRA (Fundamental Rights Agency). 2019a. Being Black in the EU. Second European Union Minorities and Discrimination Survey. Report EU-MIDIS II. Available online: https: / / fra.europa.eu/sites / default/files / fra_uploads/fra-2019-being-black-in-the-eusummary_en.pdf (accessed on 12 April 2021).

FRA (Fundamental Rights Agency). 2019b. Fundamental Rights Report 2019. Luxembourg: Publication Office of the European Union. Available online: https: / / fra.europa.eu/sites/default/files/fra_uploads / fra-2019-fundamental-rights-report-2019_en. pdf (accessed on 12 April 2021).

FRA (Fundamental Rights Agency). 2020a. Coronavirus Pandemic in the EU-Impact on Roma and Travellers. Bulletin \#5, 1 Mach-30 June. Luxembourg: Publication Office of the European Union.

FRA (Fundamental Rights Agency). 2020b. Implications of COVID-19 Pandemic on Roma and Travellers Communities. Luxembourg: Publication Office of the European Union.

Fundación Secretariado Gitano. 2013. El Impacto de la Crisis en la Comunidad Gitana. Informe Julio 2013. Madrid: Fundación Secretariado Gitano.

Fundación Secretariado Gitano. 2020. Impact of the COVID-19 Crisis on the Roma Population. Report. April. Available online: https://www.gitanos.org/upload/05/37/EN_ENCUESTA_PARTICIPANTES_FINAL.pdf (accessed on 18 April 2021).

Gabrielli, Lorenzo. 2021. El espectáculo fronterizo en las representaciones fotográficas contemporáneas de la frontera de Melilla. Un sesgo de género. In 'Espectáculo de Frontera' y Contranarrativas Audiovisuales. Edited by Amarela Varela Huertas and Mar Binimelis Adell. Bern: Peter Lang, forthcoming.

Gans, Herbert J. 2017. Racialization and Racialization Research. Ethnic and Racial Studies 40: 341-52. [CrossRef]

Gonzalez-Sobrino, Bianca, and Devon R. Goss. 2019. Exploring the mechanisms of racialization beyond the black-white binary. Ethnic and Racial Studies 42: 505-10. [CrossRef]

GRITIM-UPF. 2020. COVID-19's Impact on Migration and Migration Studies. Exploring Directions for a New Migration Research Agenda. GRITIM-UPF Policy Brief No. 9. Available online: https://repositori.upf.edu/bitstream/handle/10230/44614/2020 GRITIM-UPFPolicyBrief9.pdf?sequence=3\&isAllowed=y (accessed on 18 April 2021).

Grosfoguel, Ramón. 2004. Race and ethnicity or racialized ethcnicities? Identities within global coloniality. Ethnicities 4: 315-36. [CrossRef]

Hadj-Abdou, Leila. 2019. Immigrant integration: The governance of ethno-cultural differences. Comparative Migration Studies 7. [CrossRef]

Haller, William, Portes Alejandro, and Scott M. Lynch. 2011. Dreams Fulfilled and Shattered: Determinants of Segmented Assimilation in the Second Generation. Social Forces 89. [CrossRef]

Hellgren, Zenia, and Lorenzo Gabrielli. 2021. The Dual Expectations Gap. Divergent Perspectives on the Educational Aspirations of Spanish Roma Families. Journal of Intercultural Studies 42. [CrossRef]

Hellgren, Zenia, and Inma Serrano. 2019. Financial Crisis and Migrant Domestic Workers in Spain: Employment Opportu-nities and Conditions during the Great Recession. International Migration Review 54: 1209-29. [CrossRef]

Hellgren, Zenia. 2019. Class, race-And place: Immigrants' self-perceptions on inclusion, belonging and opportunities in Stockholm and Barcelona. Ethnic and Racial Studies 42: 2084-101. [CrossRef]

Hollinger, David. A. 2011. The concept of post-racial: How its easy dismissal obscures important questions. Daedalus 140: 174-82. [CrossRef] [PubMed]

International Labor Organization (ILO). 2014. A Precarious Position? The Labour Market Integration of New Immigrants in Spain. Report. Available online: https://www.ilo.org/wcmsp5/groups/public/---ed_protect/---protrav/---migrant/documents/ publication/wcms_313708.pdf (accessed on 12 March 2021). 
International Organization for Migration Website. 2020. Available online: https://rosanjose.iom.int/site/en/blog/intersectingdiscriminations-migrants-facing-racism?page $=30$ (accessed on 14 April 2021).

Izquierdo, Antonio. 2005. La inmigración irregular en el cambio del milenio: Una panorámica a la luz de las regularizaciones y de los contingentes anuales de trabajadores extranjeros en España. In Integraciones Diferenciadas: Migraciones en Cataluña, Galicia y Andalucía. Edited by Carlota Solé y and Antonio Izquierdo. Barcelona: Anthropos, pp. 73-88.

Johansson, Yilva. 2020. Black Lives Matter: Europe's Anti-Racism Moment European Policy Centre Keynote Address 2020. Available online: https:/ / ec.europa.eu/commission/commissioners/2019-2024/johansson/announcements/black-lives-matter-europesanti-racism-moment-european-policy-centre-keynote-address-16-july-2020_en (accessed on 16 April 2021).

Lamont, Michèle, and Virág Molnár. 2002. The Study of Boundaries in the Social Sciences. Annual Review of Sociology 28: 167-95. [CrossRef]

Leach, Colin Wayne. 2002. Democracy's Dilemma: Explaining Racial Inequality in Egalitarian Societies. Sociological Forum 17: 681-96. [CrossRef]

Lentin, Alana. 2008. Europe and the Silence about Race. European Journal of Social Theory 11: 487-503. [CrossRef]

Lentin, Alana. 2011. Racism and Ethnic Discrimination. New York: Rosen Publishing.

Lentin, Alana. 2015. What does race do? Ethnic and Racial Studies 38: 1401-6. [CrossRef]

Marí-Klose, Pau, and Álvaro Martínez Pérez. 2015. Empobrecimiento en tiempos de crisis: Vulnerabilidad y (des)protección social en un contexto de adversidad. Panorama Social 22: 11-26.

Martín Sánchez, David. 2018. Historia del Pueblo Gitano en España. Sevilla: Catarata.

McDowell, Amy. 2016. This is for the Brown Kids! Racialization and the Formation of 'Muslim' Punk Rock. Sociology of Race and Ethnicity 3: 159-71. [CrossRef]

McGarry, Aidan. 2017. Romaphobia. The Last Acceptable form of Racism. London: Zed Books.

Medina Moral, Eva, Ainhoa Herrarte, and José Vicens Otero. 2010. Inmigración y desempleo en España: Impacto de la crisis económica. Revista de Economía 584: 37-48.

Moreno, Sara, and Ramon Alòs. 2015. La inmigración en España: ¿Una integración con pies de barro? Política y Sociedad 53: 509-28. [CrossRef]

Moreno Fuentes, Francisco Javier, and Maria Bruquetas Callejo. 2011. Inmigración y Estado de Bienestar en EspañalImmigration and the Welfare State in Spain]. Social Studies No. 31, Obra Social La Caixa. Barcelona: La Caixa.

Motos Pérez, Isaac. 2009. Lo que no se olvida: 1499-1978. Anales de Historia Contemporánea 25: 58-74.

O'Hanlon, Christine. 2016. The European Struggle to Educate and Include Roma People: A Critique of Differences in Policy and Practice in Western and Eastern EU Countries. Social Inclusion 4: 1-10. [CrossRef]

Omi, Michael, and Howard Winant. 2015. Racial Formation in the United States. New York: Routledge. First published 1986.

Piper, Adrian. 1996. Out of Order, Out of Sight, Volume I: Selected Essays in Meta-Art 1968-1992. Cambridge: MIT Press.

Pla Integral del Poble Gitano. 2017-2020. The Catalan Government's Plan for Roma Integration. Available online: https: / / treballiaferssocials.gencat.cat/ca/ambits_tematics/accio_comunitaria_i_voluntariat/accio_comunitaria/poble-gitano/plaintegral/2017-2020/ (accessed on 13 March 2021).

Portes, Alejandro, and Min Zhou. 1993. The New Second Generation: Segmented Assimilation and Its Variants. The Annals of the American Academy of Political and Social Science 530: 74-96. [CrossRef]

Porthé, Victoria, Emily Ahonen, M. Luisa Vázquez, Catherine Pope, Andrés Alonso Agudelo, Ana M. García, Marcelo Amable, Fernando G. Benavides, and Joan Benach. 2010. Extending a model of precarious employment: A qualitative study of immigrant workers in Spain. American Journal of Industrial Medicine. [CrossRef]

Ramos, Cristina. 2020. Searching for Stability: Onward Migration and Pathways of Precarious Incorporation in and Out of Spain. International Migration. [CrossRef]

Rights International Spain. 2020. Roma Project. Fight against Unconscious Bias towards Roma People in the Criminal Justice System. Report, June. Available online: http:/ / www.rightsinternationalspain.org/uploads/publicacion/0ed57e0664ca283a0b89372cb0 e9245a531975c6.pdf (accessed on 18 March 2021).

Ringold, Dena, Mitchell A. Orenstein, and Wilkens Erika. 2005. Roma in an Expanding Europe: Breaking the Poverty Cycle. Washington, DC: World Bank, Available online: https:/ /openknowledge.worldbank.org/handle/10986/14869 (accessed on 18 April 2021).

Safi, Mirna. 2010. Immigrants' Life Satisfaction in Europe: Between Assimilation and Discrimination. European Sociological Review 26: 159-176. [CrossRef]

Sayyid, Salman. 2017. Post-racial paradoxes: Rethinking European racism and anti-racism. Patterns of Prejudice 51: 9-25. [CrossRef]

Seng, Julia S. 2012. Marginalized identities, discrimination burden, and mental health: Empirical exploration of an interpersonal-level approach to modelling intersectionality. Social Science \& Medicine 75: 2437-45.

Silverstein, Paul A. 2005. Immigrant Racialization and the New Savage Slot: Race, Migration, and Immigration in the New Europe. Anual Review of Anthropology 34: 363-84. [CrossRef]

Small, Stephen. 1994. Racialized Barriers: The Black Experience in the United States and England. New York and London: Routledge.

SOS Racisme. 2020. Invisibles. L'estat del Racisme a Catalunya. Informe 2019. Barcelona: Pol-len Ediciones.

Spanish Government (Ministerio de Igualdad). 2020. Report: Potential Victims' Perception of Discrimination Based on Racial or Ethnic Origin. Available online: https://igualdadynodiscriminacion.igualdad.gob.es/destacados/pdf/05-PERCEPCION_ DISCRIMINACION_RACIAL_RESUMEN-EN.pdf (accessed on 11 March 2021). 
Standing, Guy. 2014. The Precariat: The New Dangerous Class. London: Bloomsbury.

Vacca, Raffaele, Cañarte David, and Tommaso Vitale. 2021. Beyond ethnic solidarity: The diversity and specialisation of social ties in a stigmatised migrant minority. In Journal of Ethnic and Migration Studies. [CrossRef]

Van Dijk, Theun A. 2005. Discourse and Racism in Spain. Associació de Professors d'Anglès de Catalunya, 5. Available online: http:/ / www.discourses.org/OldArticles/Discourse\%20and\%20racism\%20in\%20Spain.pdf (accessed on 12 April 2021).

Vázquez García, Francisco. 2009. La Invención del Racismo: Nacimiento de la Biopolítica en España. Madrid: Akal.

Vertovec, Steven. 2007. Super-diversity and its implications. Ethnic and Racial Studies 30: 1024-54. [CrossRef]

Vincze, Enikő. 2014. The Racialization of Roma in the 'new' Europe and the political potential of Romani women. European Journal of Women's Studies 21: 443-49. [CrossRef]

Viruell-Fuentes, Edna A., Patricia Y. Miranda, and Sawsan Abdulrahim. 2012. More than culture: Structural racism, intersectionality theory, and immigrant health. Social Science \& Medicine 75: 2099-106.

Waquant, Loic. 2009. Punishing the Poor. The Neoliberal Government of Social Insecurity. Durham and London: Duke University Press.

Warmington, Paul. 2020. Critical race theory in England: Impact and opposition. Identities 27: 20-37. [CrossRef]

Young, Iris Marion. 2009. Structural Injustice and the Politics of Difference. In Contemporary Debates in Political Philosophy. Edited by Thomas Christiano and John Christman. West Sussex: Blackwell.

Zick, Andreas, Thomas F. Pettigrew, and Ulrich Wagner. 2008. Ethnic Prejudice and Discrimination in Europe. Journal of Social Issues 64: 233-51. [CrossRef] 